\title{
Spawning site selection in interior Fraser River coho salmon Oncorhynchus kisutch: an imperiled population of anadromous salmon from a snow-dominated watershed
}

\author{
Crystal J. McRae ${ }^{1,2, *}$, Kyla D. Warren ${ }^{1,3}$, J. Mark Shrimpton ${ }^{1}$ \\ ${ }^{1}$ Ecosystem Science and Management (Biology) Program, University of Northern British Columbia, Prince George, \\ British Columbia V2N 4Z9, Canada \\ ${ }^{2}$ Present Address: Committee for General Education, National Dong Hwa University, Shoufeng, Hualien, 97401 Taiwan \\ ${ }^{3}$ Present address: Rescan Environmental Services Ltd., Smithers, British Columbia V0J 2N0, Canada
}

\begin{abstract}
Understanding habitat requirements for spawning is important for species at risk of extirpation to define areas for protection of this critical life stage. Interior Fraser coho salmon (IFC) Oncorhynchus kisutch spawn in tributaries of the upper Fraser River, British Columbia, Canada. They are regionally isolated, genetically distinct, and have been listed as endangered. Recent enumeration efforts have shown declining escapement and range contraction. IFC spawn in snow-dominated watersheds, yet much of our understanding of spawner habitat requirements is based on information for coho from coastal rain-dominated systems. Consequently, we examined the relative influence of habitat features on spawning site selection. Our sampling focused on why fish chose particular locations and not others in what seemed to be suitable habitat. We defined several logistic regression models, including various combinations of physical, chemical and hydrological microhabitat features, and used an information-theoretic approach to evaluate the relative plausibility of these models. Models combining intragravel measures of electrical conductance, dissolved oxygen, temperature and specific discharge were the best models associated with spawning microhabitat selection, and jackknife validations showed that these models had good predictive abilities. Intragravel variables, therefore, appear to play a prominent role in spawning site selection for IFC. Understanding the influence of the intragravel environment on spawning site selection will help identify habitat requirements as well as potential threats to fish populations and will contribute to the development of comprehensive conservation initiatives.
\end{abstract}

KEY WORDS: Interior Fraser coho $\cdot$ Spawning $\cdot$ Site selection $\cdot$ Intragravel habitat

\section{INTRODUCTION}

Selection of a suitable site for spawning is crucial because the highest rates of mortality in salmonids generally occur during the incubation period (Quinn 2005), and this mortality is closely related to the features of the spawning/incubation site. Changes in habitat features may also be deleterious to larval development and survival. In fact, perturbation of freshwater habitat is frequently cited as a reason for declines in salmonid populations (Nehlsen et al. 1991, COSEWIC 2002). As such, the evaluation of specific spawning site features may provide vital information for conservation and management initiatives and add to the understanding of speciesspecific habitat needs.

Studies of spawning habitat requirements in salmonids have tended to focus on stream depth, ve- 
locity and physical properties of the channel, such as substrate size (Bovee 1982, Louhi et al. 2008). Others have found that not all seemingly suitable habitat for spawning is used (Mull \& Wilzbach 2007). In rivers with altered hydrographs because of hydroelectric power generation, the inclusion of stream flow fluctuation has increased the predictive ability of models (Geist et al. 2008), but apparently suitable sites are still not used for spawning. Traditional habitat features, therefore, may not provide the most effective means of assessing spawning habitat suitability (Geist \& Dauble 1998, McHugh \& Budy 2004); rather, the complexity of spawning site selection may encompass a wider range of habitat features. Surface features such as slope are associated with the potential for streambed scouring (DeVries 1997). Habitat features such as overhanging vegetation, woody debris and undercut banks have also been found to influence spawning site selection (McMahon et al. 1996). Cover features have the potential to provide protection from predators as well as adverse stream conditions, such as high stream velocity. Additionally, there may be a behavioral component to spawning site selection, as a behavioral preference for spawning on existing redds even when suitable spawning habitat was not limited has been shown (Essington et al. 1998). Conversely, spawning clusters and redd superimposition may be more effectively explained by interactions between groundwater (phreatic) and surface water (stream) that occur in the hyporheic zone (Valett et al. 1993, Geist et al. 2002).

Phreatic groundwater originates deep in the subsurface and, because of long residence times, contains a significant component of dissolved solutes (Freeze \& Cherry 1979), is devoid of oxygen (Freeze \& Cherry 1979) and shows little seasonal change in temperature (Baxter \& Hauer 2000). Similarity of water in the hyporheic zone to either phreatic water or stream water is mainly a function of the penetration depth and residence time of the hyporheic flow pathway. Stream water infiltrates the streambed (downwelling), flows through the subsurface and later emerges (upwelling) back into the stream (Boulton 1993). On a small scale, upwelling and downwelling are primarily governed by stream discharge, streambed permeability and channel morphology (Boulton 1993). Upwelling of hyporheic water has been linked to salmonid spawning sites in chinook salmon Oncorhynchus tschawytscha (Geist 2000) and rainbow trout O. mykiss (Sowden \& Power 1985), but downwelling has also been linked to spawning sites in interior snow-dominated watersheds for bull trout Salvelinus confluentus (Baxter \& McPhail 1999, Bax- ter \& Hauer 2000). Describing spawning site selection solely in terms of upwelling and downwelling may provide some insight into habitat selection cues, but this likely summarizes the driving forces behind site selection too simplistically. Additional physical and chemical features of hyporheic water are important for understanding the cues affecting spawning site selection, as well as the source of upwelling water (Alexander \& Caissie 2003).

Our study examined habitat features that influence spawning site selection for interior Fraser coho (IFC) salmon Oncorhynchus kisutch. IFC are reproductively isolated from lower Fraser River coho (Irvine 2004) and because of this are genetically distinct from coho in the lower Fraser River (Small et al. 1998). Few studies have examined spawning habitat features of interior watersheds with snow-dominated hydrological regimes, yet many populations that spawn in these regions are of conservation concern. The Committee on the Status of Endangered Wildlife in Canada (COSEWIC) concluded 'that there is a serious risk of extinction of Interior Fraser coho' (COSEWIC 2002, p. iii), and thus designated IFC as an endangered species in 2002. With this designation, IFC were considered for legal protection under the Species at Risk Act (SARA); however, based on uncertainties in the marine environment and potential socio-economic impacts, listing under SARA was denied (Canada Gazette 2006). For IFC, it has been suggested that loss of freshwater habitat is a primary factor driving current population declines (Bradford \& Irvine 2000). Freshwater habitat requirements for IFC are unknown. Studies on the habitat requirements of lower Fraser River and coastal coho populations are comparatively abundant, but may not be applicable to IFC populations. It is likely that IFC life history strategies differ from those of coastal coho populations, as interior populations evolved with substantially different hydrological regimes: interior watershed runoff is primarily snow-dominated, while coastal watershed runoff is rain-dominated. Numerous features have the potential to influence where fish spawn and it is likely that IFC select spawning sites based on particular habitat features. If known, these habitat features could be used to predict the probability of site use and such locations could be protected. To characterize habitat features important for spawning, we measured the physical and chemical features of IFC spawning sites and areas not used for spawning, fit the data to a set of plausible candidate models by logistic regression analysis, and identified the most parsimonious model(s) using an information-theoretic approach. Work was conducted in a 
watershed used as an indicator population for IFC spawner escapement.

\section{MATERIALS AND METHODS}

\section{Study site}

McKinley Creek is a tributary to the Horsefly River, located in central British Columbia, Canada, $250 \mathrm{~km}$ south of Prince George (Fig. 1). McKinley Creek is a proposed indicator watershed as it is one of the few systems where IFC have been documented to spawn and a long-term enumeration of spawners has been conducted. Anthropogenic impacts in the McKinley Creek watershed are recreation activities, logging, an enumeration fence and a temperature control structure (a dam with a fish ladder) on the creek. The enumeration fence is designed to limit upstream passage to a small portion of the river where fish can be individually counted and is located approximately $200 \mathrm{~m}$ upstream of the confluence of McKinley Creek and the Horsefly River. The McKinley Lake temperature control structure is located at the outlet of McKinley Lake, which is $\sim 12 \mathrm{~km}$ upstream of the confluence of McKinley Creek and the Horsefly River.

Stream surveys and radio telemetry were used to identify IFC spawning sites in McKinley Creek. Spe- cific spawning sites (used sites) were defined by the presence of a redd. For sample sites where no spawning occurred (unused sites), we chose locations where available habitats were within the published limits of spawning for depth, substrate and velocity. Unused sites, therefore, appeared appropriate for spawning based on habitat features of coho salmon redds in McKinley Creek, but no spawning was observed. GPS coordinates of used and unused sites were recorded and identified by pounding a steel bar into the substrate. For used sites, steel bars were pounded into the substrate at the upstream end of the redd to ensure that egg pockets were not disturbed.

\section{Spawning habitat assessment}

\section{Surface habitat features}

Physical and chemical surface habitat features were measured during the IFC spawning period (October-December). A Swoffer flow meter (Model 2100) was used to measure stream velocity $\left(\mathrm{m} \mathrm{s}^{-1}\right)$ $15 \mathrm{~cm}$ above the streambed, which represents the approximate depth a spawning fish would hold in the stream flow. Dimensions of the wetted stream channel were assessed by measuring width (m), depth (m) and streambed slope (\%). Depth at used sites was

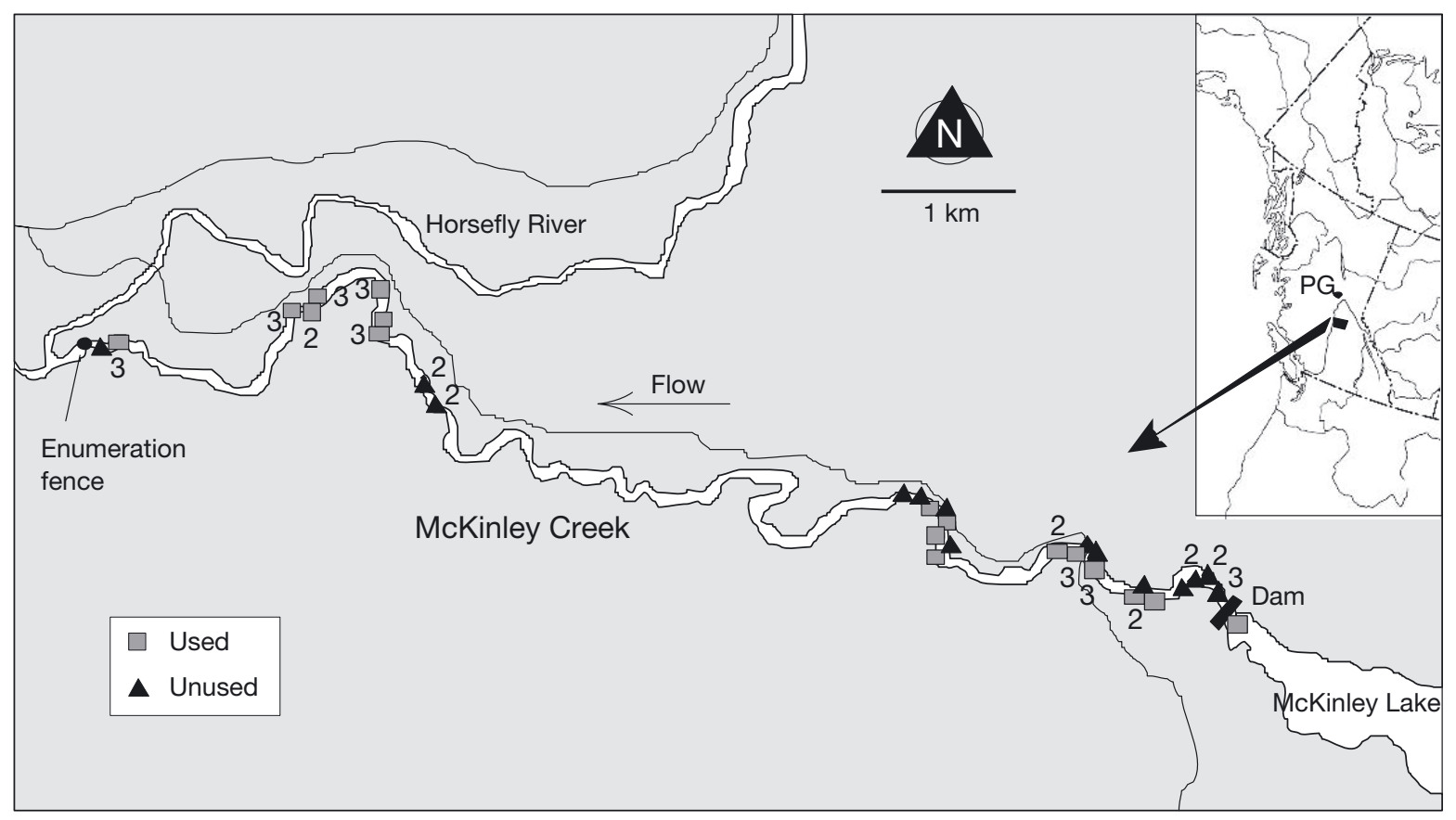

Fig. 1. Used and unused study sites and location of the McKinley Creek enumeration fence and McKinley Lake Dam. Number adjacent to symbol represents the number of spawning redds sampled that are within the area bounded by the symbol. Black lines on map represent gravel access roads. PG: Prince George, British Columbia, Canada 
measured immediately to the left upstream side of the redd to represent the original stream depth that would have been encountered prior to redd construction. Streambed slope was measured over a $6 \mathrm{~m}$ distance, which was centered over the redd (at used sites) using a clinometer. The percentage of boulder, cobble, gravel and fine sediment (fines) was estimated using coarse visual assessments at each used and unused site (\% of substrate composition in streambed surface layer). Substrate composition estimates were made to the left upstream side of the redd to mitigate for the disturbed substrate within the redd itself. Definitions of substrate size were based on a simplified version of the modified Wentworth classification as described by Cummins (1962); categories of substrate were boulder $(>256 \mathrm{~mm})$, cobble $(32-256 \mathrm{~mm})$, gravel $(4-32 \mathrm{~mm})$ and fines $(<4 \mathrm{~mm})$. Surface water was measured for dissolved oxygen using a YSI model 550A dissolved oxygen and temperature system; electrical conductance and $\mathrm{pH}$ were measured using a HANNA Instruments $\mathrm{pH} /$ EC Combo meter. Electrical conductance $\left(\mu \mathrm{Sm}^{-1}\right)$ and $\mathrm{pH}$ values were automatically temperature compensated during measurement. Dissolved oxygen was converted from $\mathrm{mg} \mathrm{l}^{-1}$ to percent saturation to mitigate for temporal temperature variation. Unused sites were identified and piezometers were installed towards the end of the spawning period to ensure that the potential influence of sampling did not affect spawning site selection. Intragravel measurements were collected for all used and unused spawning sites between November 23 and 25, 2007.

\section{Intragravel features}

Mini-piezometers were used to measure temperature, dissolved oxygen, electrical conductance, $\mathrm{pH}$, vertical hydraulic gradient and hydraulic conductivity of the intragravel environment at each study site. Mini-piezometers were constructed based on the design described by Lee \& Cherry (1978) from a $1 \mathrm{~m}$ section of polyvinyl chloride tubing attached to $15 \mathrm{~cm}$ of perforated polyethylene tubing. Ten perforations (1.5 $\mathrm{mm}$ in diameter) were made through the polyethylene tubing, which was wrapped in $250 \mu \mathrm{m}$ Nitek screen to restrict fine sediment from entering the piezometer. Piezometers were inserted into the substrate at depths of 30 and $60 \mathrm{~cm}$ at each study site. A lag bolt was inserted into the bottom end of a steel pipe that was pounded into the substrate to the desired depth. Once the desired depth was achieved, the mini-piezometer was pushed to the bottom of the pipe with a piece of rebar, which was used to hold the piezometer in place while the steel pipe was removed. At used sites, piezometers were placed upstream of redds to prevent disturbance to eggs in the redd. A syringe was used to draw water up from the piezometers to measure temperature, dissolved oxygen, electrical conductance, and $\mathrm{pH}$ of the hyporheic water. Piezometers were purged by removal of $200 \mathrm{ml}$ of water. Dissolved oxygen was calculated as percent saturation as phreatic water is low or devoid of oxygen and surface water is usually fully saturated, percent saturation provides an indication of the groundwater contribution to the hyporheic zone.

Two methods of assessing hyporheic flow within the intragravel environment were used: vertical hydraulic gradient (VHG) and hydraulic conductivity $\left(K_{\mathrm{h}}\right)$. The VHG is a unitless measurement that is positive for upwelling and negative for downwelling (Freeze \& Cherry 1979, Geist et al. 2002). A manometer, based on the design by Lee \& Cherry (1978), was used to measure the head differential that is necessary for calculating the VHG. VHG was calculated as $\mathrm{VHG}=\Delta h / \Delta L$, where $\Delta h$ is the water surface elevation inside the piezometer minus the water surface elevation of the river, and $\Delta L$ is the distance below the streambed to the first perforation in the piezometer (Freeze \& Cherry 1979). A falling-head slug test (Freeze \& Cherry 1979, Baxter et al. 2003) was used to measure hydraulic conductivity. A known volume of water $(10 \mathrm{ml})$ was added to the piezometer and the rate at which the water level returned to its initial level in the piezometer was timed. An estimate of $K_{\mathrm{h}}\left(\mathrm{cm} \mathrm{s}^{-1}\right)$ was calculated using an equation derived by Baxter et al. (2003) that was designed to be used specifically when measurement of time lag is not practical. The equation is:

$$
K_{\mathrm{h}}=\left(\frac{0.2501 d}{\Delta t}\right)\left(\frac{\log _{\mathrm{e}} h_{0}}{h}\right)
$$

where $d$ is the diameter of the piezometer, $t$ is time, $h_{0}$ is water level at time zero, and $h$ is water level at time $t$. This equation assumes isotropic flow such that the vertical and horizontal components of hydraulic conductivity are equal. VHG and $K_{\mathrm{h}}$ were used to calculate specific discharge $\left(V_{i} \mathrm{~cm} \mathrm{~s}^{-1}\right)$ at each study site using the equation $v=K_{\mathrm{h}} \mathrm{VHG}$ (Baxter et al. 2003).

\section{Data analysis}

We used an information theoretic approach (Burnham \& Anderson 2002) to construct and rank candi- 
date models from a set of predictor variables recognized as important for explaining spawner site selection (Table 1). Logistic regression models were built using data from the 2007 spawning period in the McKinley Creek watershed. Candidate models included: (1) surface variables, (2) physical and chemical variables of the intragravel environment, (3) surface and intragravel flow variables, and (4) a combination of physical, chemical and flow variables. Models included a random effect for study site location in McKinley Creek, i.e. upper and lower sections of the $12 \mathrm{~km}$ study site. This random effect was used to mitigate for potential differences that may have arisen based on the spatial gap between the upper and lower study sites. Akaike's information criterion (AIC), regression coefficients ( $\beta$ ) and standard error terms were calculated to evaluate the components of each candidate model (Burnham \& Anderson 2002). AIC values for each candidate model were corrected for small sample size $\left(\mathrm{AIC}_{\mathrm{c}}\right)$ and Akaike weights $\left(w_{i}\right)$ were also calculated for

Table 1. Summary of spawning habitat variables used for logistic regression modeling of spawning site selection of interior Fraser coho salmon in the McKinley Creek watershed during the 2007 spawning period. Location was included as a random effect in each model to account for potential differences between the upper and lower sections of the $12 \mathrm{~km}$ study site

\begin{tabular}{|c|c|c|}
\hline $\begin{array}{l}\text { Variable } \\
\text { type }\end{array}$ & $\begin{array}{l}\text { Variable } \\
\text { (units) }\end{array}$ & $\begin{array}{c}\text { Symbol/ } \\
\text { abbreviation }\end{array}$ \\
\hline \multirow[t]{8}{*}{ Surface } & Stream velocity $\left(\mathrm{m} \mathrm{s}^{-1}\right)$ & $U$ \\
\hline & Stream depth $(\mathrm{m})$ & $d$ \\
\hline & Stream width (m) & $w$ \\
\hline & Stream slope (\%) & $\mathrm{SL}$ \\
\hline & $\begin{array}{l}\text { Gravel (\% of substrate } \\
\text { composition) }\end{array}$ & $\%$ GR \\
\hline & Location & \\
\hline & $\begin{array}{l}\text { Dissolved oxygen } \\
\text { (\% saturation) }\end{array}$ & $\mathrm{DO}$ \\
\hline & $\begin{array}{l}\text { Electrical conductance } \\
\left(\mu \mathrm{S} \mathrm{cm}^{-1}\right) \\
\mathrm{pH}\end{array}$ & EC \\
\hline \multirow{3}{*}{$\begin{array}{l}\text { Flow } \\
\text { (at depths of } \\
30 \text { and } 60 \mathrm{~cm} \text { ) }\end{array}$} & $\begin{array}{l}\text { Vertical hydraulic } \\
\text { gradient }\end{array}$ & VHG \\
\hline & $\begin{array}{l}\text { Hydraulic conductivity } \\
\left(\mathrm{cm} \mathrm{s}^{-1}\right)\end{array}$ & $K_{\mathrm{h}}$ \\
\hline & $\begin{array}{l}\text { Specific discharge } \\
\left(\mathrm{cm} \mathrm{s}^{-1}\right)\end{array}$ & $v$ \\
\hline \multirow{3}{*}{$\begin{array}{l}\text { Intragravel } \\
\text { (at depths of } \\
30 \text { and } 60 \mathrm{~cm} \text { ) }\end{array}$} & $\begin{array}{l}\text { Dissolved oxygen } \\
\text { (\% saturation) }\end{array}$ & DO \\
\hline & $\begin{array}{l}\text { Electrical conductance } \\
\left(\mu \mathrm{S} \mathrm{cm}{ }^{-1}\right) \\
\mathrm{pH}\end{array}$ & EC \\
\hline & Temperature $\left({ }^{\circ} \mathrm{C}\right)$ & $T$ \\
\hline
\end{tabular}

each model to support the evidence for the top models. Models were considered equally plausible with $\mathrm{AIC}_{\mathrm{c}}$ scores within 2.0 of the best model (Burnham \& Anderson 2002).

Before conducting the logistic regression analysis, the data were examined for non-linearity, overdispersion and multicollinearity. Variables were evaluated for potential non-linear relationships by fitting models with the individual variable and comparing the fit with models with the quadratic form of the variable. Examination of linearity indicated that stream electrical conductance, stream velocity, $K_{\mathrm{h}}$ at depths of 30 and $60 \mathrm{~cm}$, as well as temperature and VHG at the $60 \mathrm{~cm}$ depth were non-linear. When a quadratic form was used in a model, the linear form of the same variable was also included. Data were checked for overdispersion by examining dispersion parameters of 3 'full' models; full models included the surface variables, the flow variables or the intragravel variables (Table 1). The full models were examined rather than the global model because of the high number of habitat variables measured. Each variable was evaluated for multicollinearity (Menard 2001), and because of the variability associated with ecological data, variance inflation factors (VIFs) were also examined for each of the candidate models to determine whether independent parameters were involved in multicollinearity; a VIF greater than 10 was considered to indicate a high degree of multicollinearity (Freund \& Wilson 1998). An examination of dispersion parameters and VIFs provided no evidence of multicollinearity and overdispersion.

Internal model validation was undertaken using a jackknife approach. A logit function was used to calculate the probability of spawning site selection for each observation in the top candidate models. Probability values from top candidate models were validated using the area under a relative operating characteristic (ROC) curve, which relates relative proportions of correctly and incorrectly classified predictions (Pearce \& Ferrier 2000); predictive ability for the top models was classified according to Swets (1988). All statistical analyses were completed using $\mathrm{R}$ (version 2.51).

\section{RESULTS}

The number of IFC spawners returning to McKinley Creek in 2007 was 5050 individuals and was the highest ever recorded. Of the over 900 redd sites identified, 34 were sampled. Many more sites were 
located than could be sampled and, as a result, a clustered sampling approach was used to focus on selected reaches that were most accessible. An additional 20 unused sites were also sampled, which included a broad range of reaches, but high flow prevented sampling in the middle section of McKinley Creek.

Combinations of 22 habitat variables were used to build 20 candidate models (Table 2). Candidate models were built using a data set that included 28 used sites and 12 unused sites; not all sites sampled were included in the analysis as not all variables could be measured for all sites. A summary of $\mathrm{AIC}_{\mathrm{C}}$ ranking indicated that there were 4 top models (Table 2). Habitat variables in the top 4 models included electrical conductance at $60 \mathrm{~cm}$ depth (Fig. 2), dissolved oxygen at $30 \mathrm{~cm}$ depth (Fig. 3), temperature at $60 \mathrm{~cm}$ depth (Fig. 4) and specific discharge at 30 and $60 \mathrm{~cm}$ depth (Fig. 5). Table 3 presents the $\beta$ coefficient, standard error, $Z$ - $(\beta / \mathrm{SE})$ and $\mathrm{p}$-values, odds ratio and the confidence interval for each variable in the top models. Electrical conductance at $60 \mathrm{~cm}$ depth was included in each of the top 4 models and $\beta$ coefficients indicated that this variable had a negative effect, such that the probability of site use decreased with increased electrical conductance. In contrast, $\beta$ coefficients of other variables included in the top models (dissolved oxygen at $30 \mathrm{~cm}$ depth, and specific discharge at 30 and $60 \mathrm{~cm}$ depth) showed a positive effect on site use. Temperature at $60 \mathrm{~cm}$ depth was found to have a positive and negative effect on site use for its linear and quadratic term, respectively.

$\mathrm{AIC}_{\mathrm{C}}$ ranking results demonstrated that the traditional habitat model, with the habitat variables of depth, velocity and a measure of substrate size (\% gravel composition of the substrate), scored relatively poorly with a rank of 16 out of 20 candidate models. In addition, models that comprised only physical and chemical surface variables were ranked poorly. Models with solely flow variables (VHG, $K_{\mathrm{h}}$ and stream velocity) also scored poorly unless they were coupled with an intragravel physical or chemical variable. Physical and chemical variables of the intragravel environment alone, or in combination with an intragravel flow variable, dominated the top 12 models.

The top 4 models had $w_{i}$ of 0.283 , $0.265,0.221$ and 0.139 , respectively and $w_{i}$ summed to 0.908. Combined $w_{i}$ by variable showed that electrical conductance at $60 \mathrm{~cm}$ had a probability of 0.983 , higher than any of the other variables. Hyporheic dissolved oxygen (30 cm depth), hyporheic temperature (60 cm depth) and specific discharge (at depths of 30 and $60 \mathrm{~cm}$ ) had probabilities of 0.296 , $0.265,0.223$ and 0.14 , respectively. Probabilities for all other habitat features were less than 0.1. Area under the ROC curve analysis produced values of $0.84,0.78,0.91$ and 0.81 for the top 4 ranked models, respectively, indicating reasonable to very good predictive ability. The area under the ROC curve value for the traditional (depth + velocity + gravel) model was 0.72 , and the value for the lowest ranked (VHG and $K_{\mathrm{h}}$ at $30 \mathrm{~cm}$ ) model was 0.55 , indicating reasonable and poor predictive ability, respectively. 


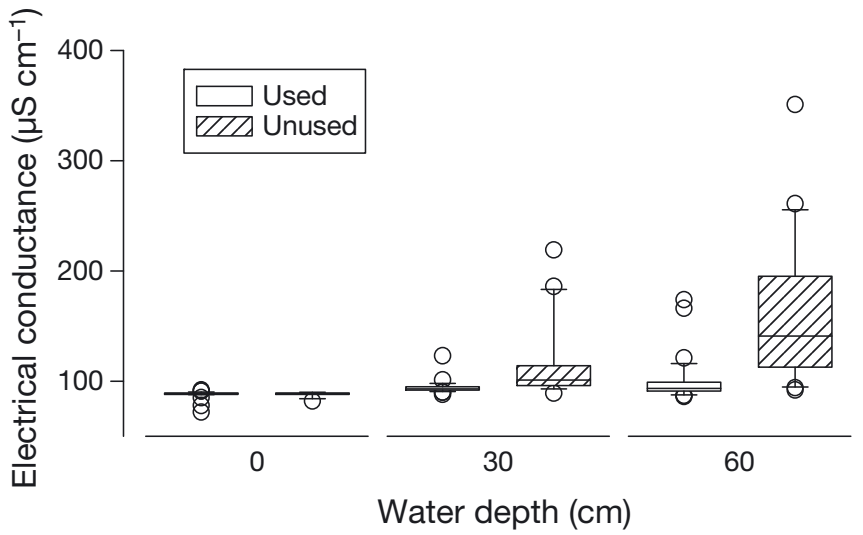

Fig. 2. Electrical conductance $\left(\mu \mathrm{S} \mathrm{cm}^{-1}\right)$ measured at used and unused study sites in the McKinley Creek watershed during the 2007 interior Fraser coho spawning period (used $\mathrm{n}=30$, unused $\mathrm{n}=17$ ); measurements were taken from surface water and hyporheic water at depths of 30 and $60 \mathrm{~cm}$. Line inside the box marks the 50th percentile; the box extends to the 25th and 75th percentiles. Capped bars indicate the 10th and 90th percentiles, and open circles represent all data outside the 10th and 90th percentiles

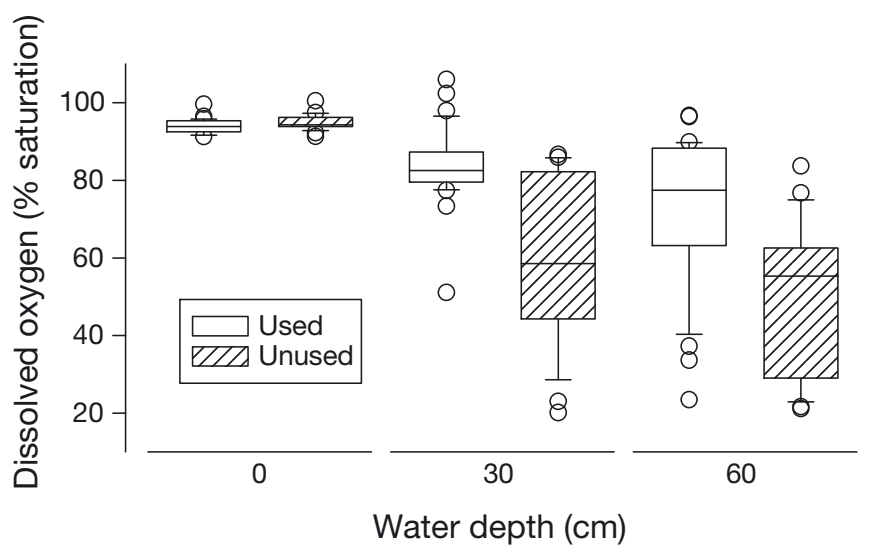

Fig. 3. Percent saturation of dissolved oxygen measured at used and unused study sites in the McKinley Creek watershed during the 2007 interior Fraser coho spawning period (used $n=31$, unused $n=18$ ); measurements were taken from surface water and hyporheic water at depths of 30 and $60 \mathrm{~cm}$. See Fig. 2 for explanation of box plots

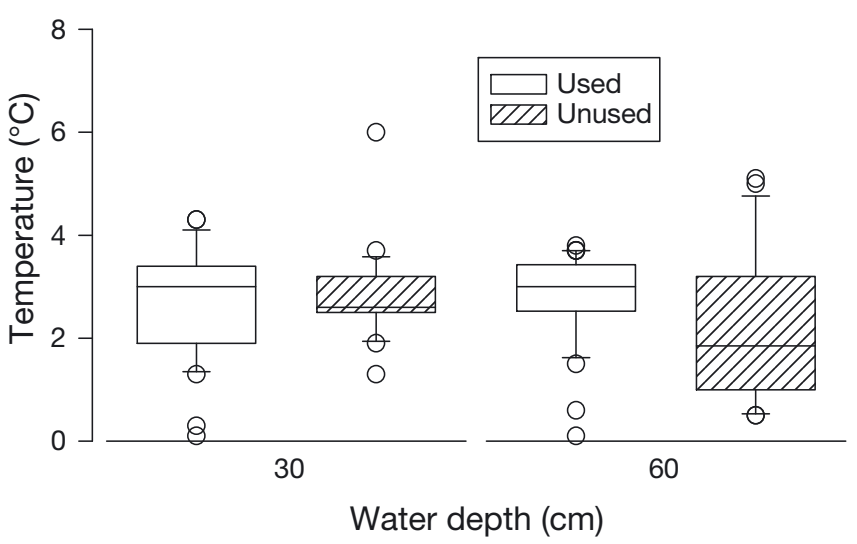

Fig. 4. Temperature $\left({ }^{\circ} \mathrm{C}\right)$ measured at used and unused study sites in the McKinley Creek watershed during the 2007 interior Fraser coho spawning period (used $n=29$, unused $n=18$ ); measurements were taken from hyporheic water at depths of 30 and $60 \mathrm{~cm}$. Surface water temperature at the time of hyporheic water sampling was $5.3 \pm 0.2^{\circ} \mathrm{C}$. See Fig. 2 for explanation of box plots

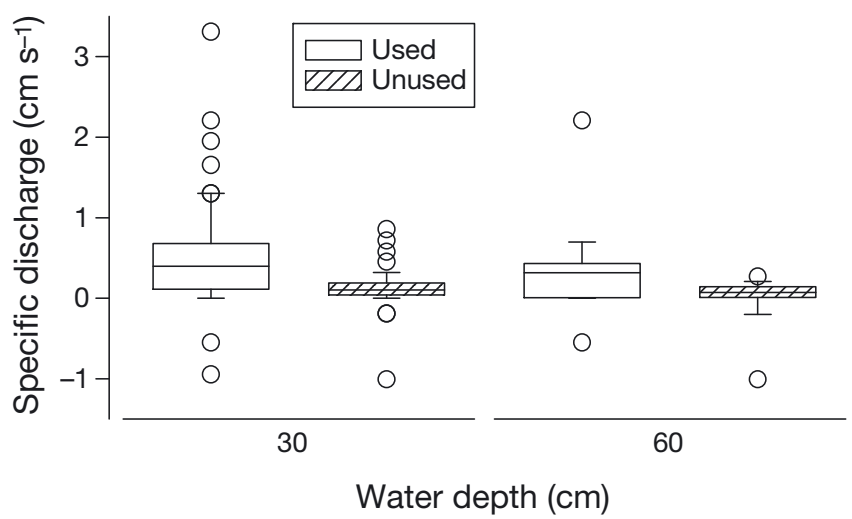

Fig. 5. Specific discharge $\left(\mathrm{cm} \mathrm{s}^{-1}\right)$ measured at used and unused study sites in the McKinley Creek watershed during the 2007 interior Fraser coho spawning period (used $n=29$, unused $n=13$ ); measurements were taken from hyporheic water at depths of 30 and $60 \mathrm{~cm}$. See Fig. 2 for explanation of box plots
Table 3. Summary of the model output for the top-ranked models for spawning site selection in interior Fraser coho in McKinley Creek watershed (used $n=28$, unused $n=12$ ). $\beta$ : regression coefficient; $Z$ : $\beta / \mathrm{SE}$. The notation of 30 or 60 indicates where measurements were taken: the intragravel environment at depths of either 30 or $60 \mathrm{~cm}$, respectively. Model variables are as defined in Table 1

\begin{tabular}{|c|c|c|c|c|c|c|c|c|}
\hline \multirow{2}{*}{$\begin{array}{l}\text { Model } \\
\text { rank }\end{array}$} & \multirow[t]{2}{*}{ Variable } & \multirow[t]{2}{*}{$\beta$} & \multirow[t]{2}{*}{$\mathrm{SE}$} & \multirow[t]{2}{*}{$Z$} & \multirow{2}{*}{$\mathrm{p}$} & \multirow{2}{*}{$\begin{array}{c}\text { Odds } \\
\text { ratio }\end{array}$} & \multicolumn{2}{|c|}{$95 \%$ CI } \\
\hline & & & & & & & Lower & Upper \\
\hline \multirow[t]{2}{*}{1} & ${ }^{30} \mathrm{DO}$ & 0.072 & 0.039 & 1.852 & 0.064 & 1.07 & -0.004 & 0.148 \\
\hline & ${ }^{60} \mathrm{EC}$ & -0.036 & 0.014 & -2.583 & 0.010 & 0.97 & -0.064 & -0.009 \\
\hline \multirow[t]{3}{*}{2} & ${ }^{60} \mathrm{~T}$ & 3.245 & 1.944 & 1.670 & 0.095 & 1.18 & -0.564 & 7.055 \\
\hline & ${ }^{60} T^{2}$ & -0.467 & 0.362 & -1.291 & 0.197 & 0.95 & -1.176 & 0.242 \\
\hline & ${ }^{60} \mathrm{EC}$ & -0.044 & 0.017 & -2.571 & 0.010 & 0.96 & -0.077 & -0.010 \\
\hline \multirow[t]{2}{*}{3} & ${ }^{30} V$ & 2.059 & 1.104 & 1.865 & 0.062 & 7.84 & -0.104 & 4.223 \\
\hline & ${ }^{60} \mathrm{EC}$ & -0.057 & 0.018 & -3.139 & 0.002 & 0.94 & -0.092 & -0.021 \\
\hline \multirow[t]{2}{*}{4} & ${ }^{60} V$ & 3.189 & 1.918 & 1.663 & 0.096 & 24.25 & -0.571 & 6.948 \\
\hline & ${ }^{60} \mathrm{EC}$ & -0.050 & 0.016 & -3.132 & 0.002 & 0.95 & -0.081 & -0.019 \\
\hline
\end{tabular}




\section{DISCUSSION}

\section{Habitat features in top-ranked models}

This study aimed to identify specific habitat features that affect IFC spawning site selection. Our results indicated the best models included electrical conductance, dissolved oxygen, temperature and specific discharge of water from the hyporheic zone.

Electrical conductance at a depth of $60 \mathrm{~cm}$ was present in each of the top 4 models. In each model, electrical conductance had a negative effect on spawning site selection, which suggests that low intragravel electrical conductance may be used as an indication of suitable habitat. Bull trout (Baxter \& Hauer 2000) and brown trout Salmo trutta (Hansen 1975) have also been found to avoid spawning in regions with high levels of electrical conductance. Areas strongly influenced by upwelling groundwater and with minimal interaction with surface water tend to have high electrical conductance (Curry \& Noakes 1995). Electrical conductance is a commonly measured feature included in assessments of salmon habitat. The potential influence on behavior and physiology is not clearly understood, but high electrical conductance may have detrimental effects on developing embryos. The gill develops initially for ion uptake rather than gas exchange in larval salmonids (Fu et al. 2010), and it has been suggested that transmembrane ion channels of larval fish are influenced by electrical conductance (Finn 2007). Interestingly, the age when ionoregulatory mechanisms develop in the gill of larval rainbow trout is independent of water hardness, indicating a lack of plasticity in gill ionoregulatory development (Fu et al. 2010). The functional significance of higher electrical conductance may be impaired physiological performance in larval fish, but this has not been examined in larval salmonids. A study on fathead minnows Pimephales promelas, however, showed slower growth in hard water, and ossification was actually enhanced in fish reared in soft water (Blanksma et al. 2009). Whether it is high electrical conductance or some other variable associated with groundwater that causes IFC to avoid certain locations is not clear. It is also possible that avoidance of locations with high electrical conductance in some regions of McKinley Creek may be due to human disturbance rather than electrical conductance directly. Many of the unused sites with high electrical conductance were either in close proximity to the gravel road that runs adjacent to portions of McKinley Creek or within $100 \mathrm{~m}$ of the McKinley Lake dam, and spawning adults may just be avoiding areas of human disturbance.
Dissolved oxygen at $30 \mathrm{~cm}$ depth tended to have a positive effect on spawning site selection and was also included in the top-ranked model, but variability in this metric was high. Dissolved oxygen has been linked to spawning site selection (Hansen 1975, Geist et al. 2002, Quinn 2005) and low dissolved oxygen concentrations have been found to reduce the survival and growth of larval fish (Alderdice et al. 1958, Crisp 2000). Rombough (1988) found that the critical oxygen level $\left(P_{\text {crit }}\right)$ during development was highest just before hatch in steelhead Oncorhynchus mykiss embryos and that $P_{\text {crit }}$ was positively associated with temperature. IFC hatch in McKinley Creek in midApril and intragravel redd temperature was recorded to be approximately $3^{\circ} \mathrm{C}$ (McRae 2009). Estimated $P_{\text {crit }}$ for developing embryos at $3^{\circ} \mathrm{C}$ is $5.5 \mathrm{mg} \mathrm{l}^{-1}$ (Rombough 1988). Interestingly, our study found that measured intragravel dissolved oxygen concentrations were seldom below this level; $85 \%$ of unused sites and $100 \%$ of the used sites had dissolved oxygen levels above $5.5 \mathrm{mg} \mathrm{l}^{-1}$, respectively. Cope \& Macdonald (1998) found no difference in dissolved oxygen concentrations between 'preferred' and 'marginal' sockeye $O$. nerka spawner habitat; over $90 \%$ of all intragravel dissolved oxygen measurements collected at a depth of $20 \mathrm{~cm}$ were greater than $6 \mathrm{mg} \mathrm{l}^{-1}$. Similar to our findings, habitat used by sockeye had a narrower range of dissolved oxygen concentrations than unused sites, but intragravel dissolved oxygen concentration may not limit potential spawning sites and suitable incubation habitat.

Although variability in temperature at $60 \mathrm{~cm}$ depth was high among our study sites, this metric had both a positive and negative effect on site use for its linear and quadratic term, respectively. Temperature affects rate of growth and development of larval fish (Heming 1982), and larval fish generally have a narrow range of temperature tolerance (Humpesch 1985). The temperature sensitivity of larval fish emphasizes the need to select spawning habitat with a temperature regime conducive to successful incubation. An additional challenge to salmonid incubation is the cold winter temperatures that are associated with interior regions. These environments have winter air temperatures that drop well below freezing and, as a result, many streams form surface and anchor ice. Anchor ice can be especially detrimental to incubating larval fish, either directly by freezing them, or indirectly by displacing portions of the substrate during intermittent warm temperatures associated with anchor ice movement (Power et al. 1999). Redds associated with groundwater upwelling have more stable temperature regimes, less surface ice and no anchor 
ice formation compared with areas with no groundwater upwelling (Hansen 1975, Baxter \& Hauer 2000). Because of the influence of groundwater, hyporheic water shows very little diurnal and seasonal variation in temperature compared with stream water and, as such, can provide a refuge for fish during temperature extremes (Power et al. 1999, Quinn 2005). In temperate regions, hyporheic water tends to be cooler than stream water in summer and warmer in winter (Cunjak \& Power 1986). The moderating effect of groundwater on temperature may be important for incubating larval fish in regions where anchor ice is prevalent (Benson 1955). Groundwater was found to moderate incubation temperatures of coho salmon redds in McKinley Creek throughout incubation. At the coldest time of the year, 15 January to 15 February, McRae (2009) showed that mean temperatures $\left( \pm 1 \mathrm{SD}\right.$ ) were $0.3 \pm 0.1^{\circ} \mathrm{C}$ and $0.7 \pm 0.2^{\circ} \mathrm{C}$ for used and unused sites, respectively. During this period, surface water averaged $0.1 \pm 0.2^{\circ} \mathrm{C}$ and at times experienced below freezing temperatures. The more stable temperature regime of the hyporheic zone, however, was coupled with lower dissolved oxygen and higher electrical conductance than the stream water (Freeze \& Cherry 1979, Geist 2000). A balance must be reached, therefore, between reducing the chance of ice formation and ensuring appropriate levels of dissolved oxygen for incubating larval fish. Used sites in McKinley Creek appear to have achieved this balance as intragravel dissolved oxygen was higher and temperature was lower than unused sites (McRae 2009). The means by which spawning fish assess this balance is unclear, but the present study indicates that hyporheic temperature may also be a cue for spawning site selection.

Hyporheic flow is typically examined in terms of VHG (positive for upwelling) and $K_{\mathrm{h}}$ (rate of intragravel water movement). Specific discharge provides a means of examining the interacting influence of these 2 measurements of hyporheic flow. There have been conflicting findings in the literature regarding the potential influence of specific discharge on spawning site selection. Although substantial evidence outlines the linkage between warmer intragravel temperatures and upwelling flow (Power et al. 1999), the precise effect of flow itself is less clear. Curry \& Noakes (1995) conducted a study in a variety of lakes and streams on the Canadian Shield and found that specific discharge did not differ significantly between used and unused brook trout Salvelinus fontinalis spawning sites, but that in general the unused sites had somewhat lower specific discharge. A study by Baxter \& McPhail (1999) on bull trout in northeastern British Columbia found that, on average, unused spawning sites were associated with negative specific discharge and used sites had positive specific discharge. Mull \& Wilzbach (2007) examined VHG as a measure of hyporheic flow and found no significant difference between used and unused sites for coastal California coho salmon. It is interesting that the studies conducted in colder snow-dominated regions showed some difference (although not a significant difference) in specific discharge between used and unused sites; this may indicate that higher levels of specific discharge are more important for populations that spawn in cold regions. Overall, specific discharge was found to have a positive effect on IFC spawning site selection.

To ensure reproductive success, female salmon likely select spawning sites that maximize the survival and growth potential for their offspring. The cue for selecting specific habitat has not been defined, but our study indicates the importance of electrical conductance, dissolved oxygen, temperature and specific discharge. The ability and mechanism for spawning fish to detect specific discharge are not known; however, it is possible that other physical and chemical features (temperature, dissolved oxygen and electrical conductance) of the intragravel environment are used to indirectly access specific discharge. For some of these variables, however, our models indicated that differences were important at intragravel depths of $60 \mathrm{~cm}$ but no differences were found at depths of $30 \mathrm{~cm}$ or at the surface. It is unlikely that spawners are able to detect differences that exist in the intragravel environment at a depth of $60 \mathrm{~cm}$. High electrical conductance, low dissolved oxygen and colder temperature (in the fall) are all characteristic of groundwater compared with surface water, but of these 3 variables, only dissolved oxygen at $30 \mathrm{~cm}$ depth was in one of the top 4 models. Oxygen-sensitive chemoreceptors have been identified on the first gill arch of rainbow trout (Burleson \& Milsom 1993). Females may be able to detect dissolved oxygen concentrations at a depth of $30 \mathrm{~cm}$ while digging a redd, and thus use dissolved oxygen concentrations as a habitat cue to determine whether a spawning site is suitable.

\section{Habitat features in poorly ranked models}

Top candidate models contained physical and chemical intragravel features, whereas surface and flow features alone ranked poorly. Surface features scored poorly because of the way unused sites were 
determined in the present study. We tried to differentiate spawning site selection within habitat that was characteristic of the published limits of spawning for depth, substrate and velocity; unused sites were chosen based on qualitative similarity to used sites and models with just these variables ranked poorly. Models containing only flow features $\left(\mathrm{VHG}, K_{\mathrm{h}}\right.$, specific discharge and velocity) also ranked poorly in the present study unless they were coupled with a physical or chemical intragravel habitat feature. Velocity has traditionally been linked to dissolved oxygen concentrations and the efficiency at which fine sediment and metabolic waste is removed from the incubation environment (Chapman 1988). Although velocity may play an important role in these processes, IFC may not specifically use velocity for selecting a spawning site. A study on steelhead embryos by Coble (1961) supports this premise; when velocity varied but oxygen concentrations remained constant, there was no survival difference during incubation. It is likely, therefore, that IFC do not detect differences in intragravel flow but use intragravel water chemistry as an indirect means of accessing hyporheic flow.

\section{Conservation and management of interior populations}

Since the 1990s, significant declines have been observed for many populations of Pacific salmon (Noakes et al. 2000). These declines are of great concern because of the ecological, economic and cultural importance of Pacific salmon. A major reason cited for declines in abundance of Pacific salmon is perturbation of critical freshwater habitat. Many of the studies examining influences of changes to freshwater habitat, however, have been conducted in coastal regions (e.g. Scrivener \& Brownlee 1989, Hartman et al. 1996). In contrast, impacts of habitat perturbation in interior regions are relatively poorly understood. Cope \& Macdonald (1998) point out the need for studies that examine the influence of habitat features on salmon in interior ecosystems specifically, before attempting to evaluate the impacts of habitat disturbance.

Cold temperatures and accessibility constraints have limited research effort in interior regions during spawning and incubation periods. Our study has highlighted important habitat features and the need for more work in these difficult environments. Habitat features are often used in modeling to predict spawning site selection in salmonids, within both natural and perturbed habitats. The transferability of habitat models from one watershed to another has been shown to have variable success for other stages of development in salmonids (Guay et al. 2003). We do not think that it is appropriate to use coastal habitat models to predict spawning site selection in interior regions because of the substantial differences in temperature and flow throughout incubation. Arguably, the greatest differences between these 2 regions occur during 2 crucial life history stages: spawning and incubation. In contrast to coastal watersheds, interior regions experience much colder temperatures and most streams develop both surface and anchor ice. Precipitation in interior regions is primarily received as snow and discharge during winter months is usually minimal. In coastal regions, precipitation is dominated by rainfall and stream discharge is more variable as it is highly correlated with the amount of rainfall received. Discharge is a major determinant of stream morphology and the formation of important microhabitats for fish (Bunn \& Arthington 2002). Within the intragravel environment, hydraulic gradient and hyporheic flow are influenced by stream discharge (Wroblicky et al. 1998). Low stream flows in winter, therefore, amplify the effect of groundwater on the intragravel environment at a time when larval salmon are developing.

\section{CONCLUSIONS}

Our results show that intragravel features appear to be the main variables driving spawning site selection at the microhabitat scale for IFC in McKinley Creek. Our study is not the first to demonstrate the importance of intragravel features. Clear linkages exist between sediment permeability and river discharge in relation to water quality in the hyporheic zone (Arntzen et al. 2006), but there is still much to be learned from examining the specific influence of hyporheic water chemistry on spawning site selection in salmonids. Our findings, however, have implications on the manner in which spawning habitat assessments are conducted, specifically those in cold interior regions. Physical and chemical characteristics of the hyporheic zone are not easily assessed, but more intensive sampling efforts are required to properly protect critical habitat. Further, factors that influence the hyporheic environment or anthropogenic disturbance that may lead to changes need to be understood. Without this knowledge, management decisions to protect spawning locations in interior snow-dominated watersheds may not be appropriate. Presently, findings from our study are being used as a foundation for further research on IFC. These 
studies will build upon our results and identify specific relationships between the hyporheic environment and IFC at critical life stages, e.g. spawning, larval incubation and juvenile rearing, in the freshwater environment.

Acknowledgements. We thank Mike Chamberlain, Dale Michie and Richard Bailey (Fisheries and Oceans Canada) for information on the McKinley Creek watershed and feedback on the project. We also thank Andrew Meshue, Cheryl Meshue and Gordon Sterritt (Northern Shuswap Tribal Council) for information on coho escapement and help in the field. We also appreciate the information and assistance provided by Rick Holmes and the staff of the Quesnel River Research Centre. Funding for this work was from the Fisheries and Oceans Canada Species at Risk Program and an NSERC Discovery Grant to J.M.S. C.J.M. received additional funding from the Peace/Williston Fish \& Wildlife Compensation Program.

\section{LITERATURE CITED}

Alderdice DW, Wickett WP, Brett JR (1958) Some effects of temporary exposure to low dissolved oxygen levels on Pacific salmon eggs. J Fish Res Board Can 15:229-250

> Alexander MD, Caissie D (2003) Variability and comparison of hyporheic water temperatures and seepage fluxes in a small Atlantic salmon stream. Ground Water 41:72-82

> Arntzen EV, Geist DR, Dresel PE (2006) Effects of fluctuating river flow on groundwater/surface water mixing in the hyporheic zone of a regulated, large cobble bed river. River Res Appl 22:937-946

Baxter CV, Hauer FR (2000) Geomorphology, hyporheic exchange, and selection of spawning habitat by bull trout (Salvelinus confluentus). Can J Fish Aquat Sci 57: 1470-1481

Baxter JS, McPhail JD (1999) The influence of redd site selection, groundwater upwelling, and over-winter incubation temperature on survival of bull trout (Salvelinus confluentus) from egg to alevin. Can J Zool 77 : 1233-1239

> Baxter C, Hauer FR, Woessner WW (2003) Measuring groundwater-stream water exchange: new techniques for installing minipiezometers and examining hydraulic conductivity. Trans Am Fish Soc 132:493-502

Benson NG (1955) Observations on anchor ice in a Michigan trout stream. Ecology 36:529-530

Blanksma C, Eguia B, Lott K, Lazorchak JM and others (2009) Effects of water hardness on skeletal development and growth in juvenile fathead minnows. Aquaculture 286:226-232

Boulton AJ (1993) Stream ecology and surface-hyporheic hydrological exchange: implications, techniques, and limitations. Aust J Mar Freshw Res 44:553-564

Bovee KD (1982) A guide to stream habitat analysis using the instream flow incremental methodology. US Fish and Wildlife Service, Instream Flow Group Information Paper 12, Fort Collins, CO

Bradford M, Irvine JR (2000) Land use, fishing, climate change, and the decline of Thompson River, British Columbia, coho salmon. Can J Fish Aquat Sci 57:13-16
Bunn SE, Arthington AH (2002) Basic principles and ecological consequences of altered flow regimes for aquatic biodiversity. Environ Manag 30:492-507

Burleson ML, Milsom WK (1993) Sensory receptors in the first gill arch of rainbow trout. Respir Physiol 93:97-110

Burnham KP, Anderson DR (2002) Model selection and inference: a practical information-theoretic approach. Springer, New York, NY

Canada Gazette (2006) Species at risk: order giving notice of decisions not to add certain species to the list of endangered species. Canada Gazette II 140:252-294

> Chapman DW (1988) Critical review of variables used to define effects of fines in redds of large salmonids. Trans Am Fish Soc 117:1-21

> Coble DW (1961) Influence of water exchange and dissolved oxygen in redds on survival of steelhead trout embryos. Trans Am Fish Soc 90:469-474

Cope S, Macdonald JS (1998) Responses of sockeye salmon (Oncorhynchus nerka) embryos to intragravel incubation environments in selected streams within the Stuart-Takla watershed. In: Brewin MK, Monita DMA (technical coordinators) Forest-fish conference: land management practices affecting aquatic ecosystems. Proceedings of the Forest-Fish Conference, Natural Resources Canada, Edmonton, p 283-294

COSEWIC (Committee on the Status of Endangered Wildlife in Canada) (2002) COSEWIC assessment and status report on the coho salmon Oncorhynchus kisutch (Interior Fraser population) in Canada. COSEWIC, Ottawa

Crisp TD (2000) Trout and salmon: ecology, conservation, and rehabilitation. Fishing New Books, Oxford

> Cummins KW (1962) An evaluation of some techniques for the collection and analysis of benthic samples with special emphasis on lotic waters. Am Midl Nat 67: 477-504

> Cunjak RA, Power G (1986) Winter habitat utilization by stream resident brook trout (Salvelinus fontinalis) and brown trout (Salmo trutta). Can J Fish Aquat Sci 43: 1970-1981

Curry RA, Noakes DLG (1995) Groundwater and the selection of spawning sites by brook trout (Salvelinus fontinalis). Can J Fish Aquat Sci 52:1733-1740

DeVries P (1997) Riverine salmonid egg burial depths: review of published data and implications for scour studies. Can J Fish Aquat Sci 54:1685-1698

Essington TE, Soreensen PW, Paron DG (1998) High rate of redd superimposition by brook trout (Salvelinus fontinalis) and brown trout (Salmo trutta) in a Minnesota stream cannot be explained by habitat availability alone. Can J Fish Aquat Sci 55:2310-2316

- Finn RN (2007) The physiology and toxicology of salmonid eggs and larvae in relation to water quality criteria. Aquat Toxicol 81:337-354

Freeze RA, Cherry JA (1979) Groundwater. Prentice-Hall, Englewood Cliffs, NJ

Freund RF, Wilson WJ (1998) Regression analysis: statistical modeling of a response variable. Academic Press, San Diego, CA

Fu C, Wilson JM, Rombough PJ, Brauner CJ (2010) Ions first: $\mathrm{Na}^{+}$uptake shifts from the skin to the gills before $\mathrm{O}_{2}$ uptake in developing rainbow trout, Oncorhynchus mykiss. Proc Biol Sci 277:1553-1560

Geist DR (2000) Hyporheic discharge of river water into fall chinook salmon spawning areas in the Hanford Reach, Columbia River. Can J Fish Aquat Sci 57:1647-1656 
Geist DR, Dauble DD (1998) Redd site selection and spawning habitat use by fall chinook salmon: the importance of geomorphic features in large rivers. Environ Manag 22: 655-669

Geist DR, Hanrahan TP, Arntzen EV, McMichael GA, Murray CJ, Chien YJ (2002) Physiochemical characteristics of the hyporheic zone affect redd site selection by chum salmon and fall chinook salmon in the Columbia River. N Am J Fish Manag 22:1077-1085

Geist DR, Murray CJ, Hanrahan TP, Xie YL (2008) A model of the effects of flow fluctuations on fall chinook salmon spawning habitat availability in the Columbia River. N Am J Fish Manag 28:1894-1910

Guay J, Boisclair D, Leclerc M, Lapointe M (2003) Assessment of the transferability of biological habitat models for Atlantic salmon parr (Salmo salar). Can J Fish Aquat Sci 60:1398-1408

Hansen EA (1975) Some effects of groundwater on brown trout redds. Trans Am Fish Soc 104:100-110

> Hartman GF, Scrivener JC, Miles MJ (1996) Impacts of logging in Carnation Creek, a high-energy coastal stream in British Columbia, and their implication for restoring fish habitat. Can J Fish Aquat Sci 53(Suppl. 1):237-251

Heming TA (1982) Effects of temperature on utilization of yolk by chinook salmon (Oncorhynchus tshawytscha) eggs and alevins. Can J Fish Aquat Sci 39:184-190

Humpesch UH (1985) Inter-and intra-specific variation in hatching success and embryonic development of five species of salmonids and Thymallus thymallus. Arch Hydrobiol 104:129-144

Irvine JR (2004) Climate change, adaptation, and 'endangered' salmon in Canada. In: Hooper TD (ed) Proc Species at Risk 2004 Pathways to Recovery Conference. Conference Organizing Committee, Victoria, p 1-8

Lee DR, Cherry JA (1978) A field exercise on groundwater flow using seepage meters and mini-piezometers. J Geol Educ 27:6-10

Louhi P, Maki-Petays A, Erkinaro J (2008) Spawning habitat of Atlantic salmon and brown trout: general criteria and intragravel factors. River Res Appl 24:330-339

McHugh P, Budy P (2004) Patterns of spawning habitat selection and suitability for two populations of spring chinook salmon, with an evaluation of generic versus site-specific suitability criteria. Trans Am Fish Soc 133: 89-97

McMahon TE, Zale AV, Orth DJ (1996) Aquatic habitat measurements. In: Murphy BR, Willis DW (eds) Fisheries techniques. American Fisheries Society, Bethesda, MD, p 83-120

Editorial responsibility: Craig Paukert, Columbia, Missouri, USA
McRae CJ (2009) Spawning site selection and the influence of incubation environment on larval success in Interior Fraser coho. MSc thesis, University of Northern British Columbia, Prince George

Menard S (2001) Applied logistic regression. Sage University Papers Series on Quantitative Applications in the Social Sciences, 07-106. Sage, Thousand Oaks, CA

Mull KE, Wilzbach MA (2007) Selection of spawning sites by coho salmon in a northern California stream. N Am J Fish Manag 27:1343-1354

Nehlsen W, Williams JE, Lichatowich JA (1991) Pacific salmon at the crossroads: stocks at risk from California, Oregon, Idaho, and Washington. Fisheries 16:4-21

Noakes DJ, Beamish RJ, Kent ML (2000) On the decline of Pacific salmon and speculative links to salmon farming in British Columbia. Aquaculture 183:363-386

$>$ Pearce J, Ferrier S (2000) Evaluating the predictive performance of habitat models developed using logistic regression. Ecol Model 133:225-245

> Power G, Brown RS, Imhof JG (1999) Groundwater and fish: insights from northern North America. Hydrol Processes 13:401-422

Quinn TP (2005) The behavior and ecology of Pacific salmon and trout. University of Washington Press, Seattle, WA

Rombough PJ (1988) Growth, aerobic metabolism, and dissolved oxygen requirements of embryos and alevins of steelhead, Salmo gairdneri. Can J Zool 66:651-660

Scrivener JC, Brownlee MJ (1989) Effects of forest harvesting on spawning gravel and incubation survival of chum (Oncorhynchus keta) and coho salmon (Oncorhynchus kisutch) in Carnation Creek, British Columbia. Can J Fish Aquat Sci 46:681-696

> Small MP, Beacham TD, Withler RE, Nelson RJ (1998) Discriminating coho salmon (Oncorhynchus kisutch) populations within the Fraser River, British Columbia, using microsatellite DNA markers. Mol Ecol 7:141-155

$>$ Sowden TK, Power G (1985) Prediction of rainbow trout embryo survival in relation to groundwater seepage and particle size of spawning substrates. Trans Am Fish Soc 114:804-812

Swets JA (1988) Measuring the accuracy of diagnostic systems. Science 240:1285-1293

> Valett HM, Hakenkamp CC, Boulton AJ (1993) Perspectives on the hyporheic zone, integrating hydrology and biology, introduction. J N Am Benthol Soc 12:40-43

Wroblicky GJ, Campana ME, Valett HM, Dahm CN (1998) Seasonal variation in surface-subsurface water exchange and lateral hyporheic area of two stream-aquifer systems. Water Resour Res 34:317-328

Submitted: May 2, 2011; Accepted: November 14, 2011 Proofs received from author(s): February 25, 2012 